\title{
Evaluation of fetal stress in preeclamptic patients
}

\author{
Esra Can ${ }^{1}$ (iD), Oluş Api ${ }^{2}$ (iD \\ ${ }^{1}$ Department of Gynecology and Obstetrics, Kanuni Sultan Siileyman Training and Research Hospital, Istanbul, Turkey \\ ${ }^{2}$ Department of Gynecology and Obstetrics, American Hospital, Istanbul, Turkey
}

\begin{abstract}
Objective: Previous studies have established the association between preeclampsia (PE)-induced stress on fetus and elevated 17-hydroxyprogesterone levels (17-OHP) of which known as a stress markers. The aim of our study was to evaluate the relationship between these markers that were analyzed via cord blood with the severity of PE.

Methods: Consecutive PE women who were admitted to Dr. Lütfi Kırdar Training and Research Hospital Obstetrics and Gynecology Clinics from August 2009 to December 2009 were recruited. Uncomplicated pregnant women admitted at the same period consisted the control group. Umbilical blood samples were collected from umbilical artery immediately after birth and 17-OHP analyzed.

Results: The study group consisted of 40 mild PE $(n=12)$ and severe PE patients $(n=28)$ and the control group consisted of 35 patients. Maternal age and body mass index were similar between the study groups, but the fetuses in the severe PE group had a smaller mean gestational age and mean birth weight $(\mathrm{p}=0.001)$. Umbilical cord 17 OHP levels were statistically significantly lower in the severe PE patients than the controls [Control group $=12.5 \pm 4.6(\mathrm{n}=35)$; mild $\mathrm{PE}=10.3 \pm 6 \quad(\mathrm{n}=12, \mathrm{p}=0.24)$, severe $\mathrm{PE}=9.6 \pm 5.2 \quad(\mathrm{n}=28, \mathrm{p}=0.019)]$. Although the patients with mild PE had lower 17-OHP levels, they were not statistically significant $(\mathrm{p}=0.827)$.

Conclusion: In our study, it is found that there is no association between PE severity and the cord blood levels of 17-OHP. The effect of early intervention that prevent feto-maternal complications may lead to normal or low levels of these markers of which was found increased in cord blood of preeclamptic patients in previous studies.
\end{abstract}

Keywords: Preeclampsia, umbilical cord, chronic fetal stress, stress markers.

\section{Introduction}

Preeclampsia is associated with placental oxidative stress, which in turn is associated with maternal and indirect fetal damage at different levels. ${ }^{[1-4]}$ The effect on the

\section{Özet: Preeklamptik hastalarda fetal stresin değerlendirilmesi}

Amaç: Daha önceki çalışmalar, stres belirteçleri olarak bilinen artmış 17-hidroksiprogesteron seviyeleri (17-OHP) ile fetüsteki preeklampsiye (PE) bağlı stres arasındaki ilişkiyi ortaya koymuştur. Çalışmamızın amacı, kordon kanıyla analiz edilen bu belirteçler ile preeklampsi şiddeti arasındaki ilişkiyi değerlendirmekti.

Yöntem: Ağustos 2009 ile Aralık 2009 tarihleri arasında Dr. Lütfi Kırdar Eğitim ve Araştırma Hastanesi Kadın Hastalıkları ve Doğum Kliniğine başvuran ardışık preeklampsi olguları çalışmaya dahil edildi. Aynı dönemde başvuran komplikasyonsuz gebeler ise kontrol grubunu oluşturdu. Doğumun hemen ardından umbilikal arterden umbilikal kan örnekleri alındı ve 17-OHP analiz edildi.

Bulgular: Çalışma grubu 40 hafif $\mathrm{PE}(\mathrm{n}=12)$ ve şiddetli PE ( $\mathrm{n}=28)$ olgularından, kontrol grubu ise 35 hastadan oluşmaktaydı. Maternal yaş ve vücut kitle indeksi değerleri çalışma grupları arasında benzerdi, ancak şiddetli PE grubundaki fetüsler daha küçük ortalama gestasyonel yaşa ve ortalama doğum ağırlığına sahipti $(\mathrm{p}=0.001)$. Umbilikal kordon 17-OHP seviyeleri kontrol grubuna kıyasla şiddetli PE hastalarında istatistiksel olarak anlamlı şekilde daha düşüktü [Kontrol grubu=12.5 $\pm 4.6(n=35)$; hafif $P E=10.3 \pm 6 \quad(n=12, p=0.24)$, şiddetli $\mathrm{PE}=9.6 \pm 5.2(\mathrm{n}=28, \mathrm{p}=0.019)]$. Hafif $\mathrm{PE}$ hastalarında 17-OHP seviyeleri daha düşük olsa da istatistiksel olarak anlamlı değildi ( $\mathrm{p}=0.827$ ).

Sonuç: Çalışmamızda, PE şiddeti ile kordon kanı 17-OHP seviyeleri arasında hiçbir ilişki bulmadık. Feto-maternal komplikasyonları önleyen erken müdahale etkisi, daha önceki çalışmalarda preeklamptik hastaların kordon kanında arttı̆̆ tespit edilen bu belirteçlerin normal veya düşük seviyelere sahip olmasını sağlayabilir.

Anahtar sözcükler: Preeklampsi, umbilikal kordon, kronik fetal stres, stres belirteçleri.

mother is commonly associated with increased endovascular dysfunction, cardiovascular mortality and morbidity, and as the severity increases, it affects the broad spectrum to the extent of common organ damage. ${ }^{[5-8]}$ The

Correspondence: Esra Can, MD. Department of Gynecology and Obstetrics, Kanuni Sultan Süleyman Training and Research Hospital, Istanbul, Turkey. e-mail: dresraoten@yahoo.com / Received: December 23, 2019; Accepted: February 17, 2020

Please cite this article as: Can E, Api O. Evaluation of fetal stress in preeclamptic patients. Perinatal Journal 2020;28(1):7-10. doi: $10.2399 /$ prn.20.0281002 
main effect on the fetus is inadequate nutrition, a consequence of uteroplacental vascular insufficiency, resulting in growth restriction. These low weight babies not only have acute problems, but also lead to long-term negative consequences, such as future cardiovascular risks. ${ }^{[9,10]}$ The early recognition of fetal stress caused by preeclampsia and therefore the prevention of perinatal mortality and morbidity has been the main goal of many clinical trials. For all these reasons, markers have been found to be able to detect preeclampsia-related fetal lethargy severity or to be able to recognize beforehand without severe damage. Despite the many studies conducted so far, markers with high sensitivity and specificity, which can still predict the development of the disease, have not been identified.

The earliest studies that could lead to fetal distress have been tried to make early diagnosis by using machine-based methods such as ultrasonography and cardiotocography, from the physical examination that can measure the rudimentary indication of fetal growth, such as the measurement of the uterine fundus and the abdominal circumference of each antenatal visit. Besides, many studies have used stress hormones and some biochemical markers released to uteroplacental hypoperfusion. The most common of these biochemical markers is hormonebased, and 17-hydroxyprogesterone (17-OHP) levels, which is the pioneer of the cortisol pathway, are thought to be used as an intrauterine stress indicator. ${ }^{[1]}$

In this study, we aimed to determine whether the effect of preeclampsia on umbilical cord blood of fetuses born from preeclamptic mothers is correlated with 17OHP levels, which were previously reported as fetal stress marker, and to investigate whether there is a relationship between the levels of these marker and severity of preeclampsia.

\section{Methods}

The study protocol was approved by the local ethics committee and informed consent was obtained from each participating patient. Pregnancies complicated by preeclampsia are defined as having at least two separate measurements of systolic blood pressure $\geq 140 / 90 \mathrm{mmHg}$ and diastolic blood pressure $\geq 90 \mathrm{mmHg}$ and presence of proteinuria (>300 $\mathrm{mg} / 24 \mathrm{~h}$ or ++ over the spot urine assay). The systolic pressure measured at the sitting position following a 10 minute or more rest period as described in the blood pressure ACOG 2002 Clinical
Practice Guide was assessed on the basis of the Korotkoff 1st auscultation sound, and the diastolic blood pressure was assessed on the basis of the Korotkoff 5th auscultation sound.

After resting for 10 minutes, the pregnant women who had high blood pressure were taken to rest and blood pressure was measured again after 6 hours and the pregnant women with blood pressure of 140/90 $\mathrm{mmHg}$ or more were accepted as hypertensive and in the spot urine analysis, $1+$ and over-determined pregnancies were included in the study with the diagnosis of preeclampsia.

All severe preeclamptic pregnancies received eclampsia prophylaxis treatment with magnesium sulphate according to the Parkland protocol. ${ }^{[12]}$ The criteria specified in the ACOG 2002 Clinical Practice Guideline were used to determine mild and severe preeclampsia cases. Similarly, for the control group, healthy pregnancies were applied during the same gestational week.

The exclusion criteria are defined as follows:

- Chronic hypertension, diabetes mellitus, antiphospholipid antibody syndrome, liver or kidney disease, previous thromboembolic syndrome and thrombophilia, multiple pregnancy,

- Fetal congenital malformation, chromosome anomalies, intrauterine infection

- Patients with a known disease that affects the platelet count and liver enzymes.

A detailed history of all cases included in the study was taken and obstetric information was recorded. When patients were admitted to the hospital, full blood count, biochemical analysis, stool urine test were performed. Umbilical blood samples were taken from the umbilical artery immediately after the umbilical artery was clamped during delivery. The samples were centrifuged at $2500 \times \mathrm{g}$ for 10 minutes. Serum and plasma samples were separated and frozen and then stored at $-80{ }^{\circ} \mathrm{C}$. The samples were studied at Dr. Lütfi Kirdar Kartal Training and Research Hospital Biochemistry Laboratory. Dissemination preparation was prepared from the cord blood and the preparations were evaluated in Hematology Lab. 17-OH progesterone was studied with Enzyme-linked immunosorbent assay performed manually and EL×50 was measured with a washing device using an $\mathrm{EL} \times 800$ microplate reader. 


\section{Statistical analysis}

For the statistical evaluation of the data, the numerical data obtained from the events were coded and transferred to the computer program. Descriptive and analytical statistics were performed using The Statistical Package for Social Sciences (SPSS) 16.0 (SPSS Inc., Chicago, IL, USA).

The normal distribution of the parameters of the groups was assessed by the Kolmogorov-Smirnov test. The significance of the difference between the numerical variables in the three groups was assessed by the Kruskal-Wallis test. In the case of a significant difference between the groups in the Kruskal-Wallis test, the Mann-Whitney $U$ test was applied in the bilateral comparisons between the groups in order to test where the difference originated. A statistical significance level of $\mathrm{p}<0.05$ was accepted as the threshold value.

\section{Results}

During the study period, all preeclamptic pregnant women $(n=40)$ and noncomplicated pregnant women $(\mathrm{n}=35)$ were taken to our clinic. The study group was divided into 2 subgroups as mild preeclamptic group $(n=12)$ and severe preeclamptic group $(n=28)$.

A total of 75 patients were included in the study group; 35 (46.6\%) of these patients were control group, 12 (16\%) were mild PE group and 28 (37.3\%) were severe PE group. Table 1 shows the comparison of maternal age, gestational age at birth, maternal birth weight and maternal BMI (body mass index) values in the study and control group.

When the study and control groups were examined, no statistically significant difference was observed between those groups in terms of mean maternal age, $\mathrm{BMI}$ and gestational age. Birth weights were significantly different between the groups $(\mathrm{p}=0.001$ for both groups). The mean birth weights of babies born from severe preeclamptic pregnancies were significantly lower than the other groups.

The mean 17-OHP levels of the umbilical cord are given in Table 2. Umbilical cord 17-OHP levels were found to be lower in mild preeclampsia than controls, but this difference was significantly lower in severe PE compared to controls, while the difference did not reach statistical significance.
Table 1. Demographic characteristics of patients in study and control groups.

\begin{tabular}{|c|c|c|c|c|}
\hline & $\begin{array}{l}\text { Control } \\
(n=35)\end{array}$ & $\begin{array}{c}\text { Mild PE } \\
(\mathrm{n}=12)\end{array}$ & $\begin{array}{c}\text { Severe PE } \\
(\mathrm{n}=28)\end{array}$ & p-value \\
\hline Age (year) & $27.1 \pm 6.2$ & $29.8 \pm 5.7$ & $26.8 \pm 5.3$ & 0.206 \\
\hline Gestastional age (month) & $38.5 \pm 1.8$ & $37.8 \pm 1.4$ & $37.7 \pm 3.7$ & 0.2 \\
\hline Birth weight (g) & $3243 \pm 551$ & $2805 \pm 458$ & $2215 \pm 833$ & 0.001 \\
\hline Mother BMI $\left(\mathrm{kg} / \mathrm{cm}^{2}\right)$ & $28.3 \pm 3$ & $29 \pm 3.4$ & $30.1 \pm 3.9$ & 0.08 \\
\hline
\end{tabular}

BMI: body mass index; PE: preeclampsia. All values are expressed as mean \pm standard deviation (SD).

\section{Discussion}

In our study, it is found that there is no association between PE severity and the cord blood 17-OHP levels. In contrast to other studies, there was no statistically significant difference between control group and preeclampsia group in terms of 17-OHP values used as chronic stress indicator. Moreover, our study, as opposed to other studies, showed lower 17-OHP levels when compared to the control group with severe preeclampsia. Preeclampsia is a complex disease affecting $3-4 \%$ of all pregnancies and causing maternal mortality to more than per year in general. Screening tests (commonly used, which are simple, non-invasive, fast results, cheap, high sensitivity and predictive value) are ideal for predicting such a high risk clinical condition, ideal for minimizing mortality and morbidity. The physiological role of 17-OHP, one of the stress markers we use in our study and is a precursor molecule in the pathway of cortisol synthesis, has been clearly shown. Cortisol releasing hormone, cortisol and dehydroepiandrosterone sulfate levels were found to be significantly higher in the cord blood of infants of preeclamptic mothers examined in the literature than in healthy infants. ${ }^{[1,14]}$

Umbilical cord blood 17-OHP levels were investigated in our study and unlike the expectation, no significant difference was found in the preeclamptic group. On the contrary, the numerically lowest values were found in the heavily eclamptic group. In a study of Ersch

Table 2. Umbilical cord 17-OHP levels.

\begin{tabular}{|c|c|c|c|}
\hline Variable & Control $(n=35)$ & Mild PE (n=12) & Severe PE $(n=28)$ \\
\hline 17-OHP (pg/ml) & $12.59 \pm 4.65$ & $10.3 \pm 6.05$ & $9.6 \pm 5.24^{*}$ \\
\hline
\end{tabular}


et al., in premature infants due to preeclampsia and amniotic fluid infection, there was no change in fetal $\mathrm{pH}$, Apgar score and baseline as an indicator of acute stress. However, 17-OHP levels and birth weight which are used as chronic stress markers were markedly elevated. In the upper zone of the reference range for 17-OHP, preeclamptic mothers' infants were included. ${ }^{[1]}$ It is interpreted that 17-OHP may be used as a chronic stress indicator because it is thought that cortisol level may be affected by many factors which are an acute marker. The uncertainty of the reference range of the 17-OHP level clearly indicates the changes in fetal immature weight and low birth weight at 17-OHP level is unknown. The authors also argued that the 17-OHP level could be used as a chronic stressor, and that pregnant woman who had an amniotic fluid infection, an acute stress, could be used as a comparative group. Our study was a comparison of 17-OHP levels with preeclampsia severity and it is a comparison of two chronic stress groups (severe and mild $\mathrm{PE}$ ) with the control group rather than acute and chronic stress. Our work cannot be identified as a stressor, because it is unclear how 17-OHP levels detected by fetal cord blood are affected by maternal and placental and fetal cortisol levels and how the feto-maternal adaptation process will respond.

\section{Conclusion}

There was no correlation between cord blood 17-OHP levels and preeclampsia severity. However, it can be assumed that early intervention applied to preeclamptic pregnancies may have removed the chronic stress that may arise in the fetus.

Conflicts of Interest: No conflicts declared.

\section{References}

1. Duley L. Pre-eclampsia and the hypertensive disorders of pregnancy. Br Med Bull 2003;67:161-76.

2. ACOG Committee on Obstetric Practice. ACOG practice bulletin. Diagnosis and management of preeclampsia and eclamp- sia. American College of Obstetricians and Gynecologists. Int J Gynaecol Obstet 2002;77:67-75.

3. Redman CW, Sargent IL. Latest advances in understanding preeclampsia. Science 2005;308:1592-4.

4. Roberts JM, Redman CW. Preeclampsia: more than pregnancy-induced hypertension. Lancet 1993;341:1447-51.

5. Barker DJ. Fetal origins of cardiovascular disease. Ann Med 1999;31 Suppl 1:3-6.

6. Roberts JM, Pearson GD, Cutler JA, Lindheimer MD; National Heart Lung and Blood Institute. Summary of the NHLBI Working Group on Research on Hypertension During Pregnancy. Hypertens Pregnancy 2003;22:109-27.

7. Consensus Report: National High Blood Pressure Education Program Working Group Report on high blood pressure in pregnancy. Am J Obstet Gynecol 1990;163:1689-1712.

8. Levine RJ, Ewell MG, Hauth JC, Curet LB, Catalano PM, Morris CD, et al.. Should the definition of preeclampsia include a rise in diastolic blood pressure of $15 \mathrm{~mm} \mathrm{Hg}$ to a level $90 \mathrm{~mm} \mathrm{Hg}$ in association with proteinuria? Am J Obstet Gynecol 2000;183:787-92.

9. Carr H, Cnattingius S, Granath F, Ludvigsson JF, Edstedt Bonamy AK. Preterm birth and risk of heart failure up to early adulthood. J Am Coll Cardiol 2017;69:2634-42.

10. Kuhle S, Maguire B, Ata N, MacInnis N, Dodds L. Birth weight for gestational age, anthropometric measures, and cardiovascular disease markers in children. J Pediatr 2017;182:99106.

11. Ersch J, Beinder E, Stallmach T, Bucher HU, Torresani T. 17-Hydroxyprogesterone in premature infants as a marker of intrauterine stress. J Perinat Med 2008;36:157-60.

12. Luger R, Arnold J. Pregnancy, hypertension. 2017 May 3. StatPearls [Internet]. Treasure Island, FL: StatPearls Publishing; 2017 Jun 3.

13. Giles WB, McLean M, Davies JJ, Smith R. Abnormal umbilical artery Doppler waveforms and cord blood corticotropinreleasing hormone. Obstet Gynecol 1996;87:107-11.

14. Goland RS, Tropper PJ, Warren WB, Stark RI, Jozak SM, Conwell IM. Concentrations of corticotrophin-releasing hormone in the umbilical-cord blood of pregnancies complicated by pre-eclampsia. Reprod Fertil Dev 1995;7:1227-30.

Bu makalenin kullanım izni Creative Commons Attribution-NoCommercial-NoDerivs 3.0 Unported (CC BY-NC-ND3.0) lisansı aracılığılyla bedelsiz sunulmaktadir. / This work is licensed under the Creative Commons Attribution-NonCommercial-NoDerivs 3.0 Unported (CC BY-NC-ND3.0) License. To view a copy of this license, visit http://creativecommons.org/licenses/by-nc-nd/3.0/ or send a letter to Creative Commons, PO Box 1866 , Mountain View, CA 94042, USA. 